REGARDS

SUR LEECONOMIE ALLEMAND

BULLETIN ECONOMIQUE DU CIRAC
Regards sur l'économie allemande

Bulletin économique du CIRAC

$75 \mid 2006$

Varia

\title{
Bureaucratie : elle accapare 4,2 milliards $€$ par an
}

Isabelle Bourgeois

\section{OpenEdition}

\section{Journals}

Édition électronique

URL : http://journals.openedition.org/rea/847

DOI : $10.4000 /$ rea. 847

ISBN : 978-2-8218-0846-1

ISSN : 1965-0787

Éditeur

CIRAC

Édition imprimée

Date de publication : 1 mars 2006

Pagination : 38

ISSN : 1156-8992

Référence électronique

Isabelle Bourgeois, "Bureaucratie : elle accapare 4,2 milliards € par an », Regards sur l'économie allemande [En ligne], 75 | mars 2006, document 3, mis en ligne le 20 mai 2008, consulté le 15 septembre 2020. URL : http://journals.openedition.org/rea/847

Ce document a été généré automatiquement le 15 septembre 2020.

(C) CIRAC 


\title{
Bureaucratie : elle accapare 4,2 milliards $€$ par an
}

\author{
Isabelle Bourgeois
}

La débureaucratisation pourrait créer 600000 emplois et générer un surplus de croissance de 30 milliards $€$, affirme l'Institut der Deutschen Wirtschaft proche du BDI. La Fédération des CCI allemandes (DIHT) aboutit aux mêmes conclusions, de même que l'Institut für Mittelstandforschung à qui le ministère fédéral de l'Economie avait confié une estimation chiffrée du coût entraîné pour les entreprises par les formalités administratives. Globalement, il dépasse les 4,2 milliards $€$ par an - somme des seuls coûts salariaux requis pour la gestion des formalités (à quoi il faudrait ajouter $30 \%$ de frais généraux). Trois procédures se taillent la part du lion : les déclarations douanières (766,2 millions $€$ ), de TVA (543,6 millions $€$ ) et de revenus (275,3 millions $€$ ). En quatrième position vient l'établissement de certificats de travail en cas de licenciement.

\section{INDEX}

Mots-clés : administration, bureaucratie, finances publiques, politique économique 